\title{
The Synergistic Effect of Insurance and Banking Sector Activities on Economic Growth in Africa
}

Mehmet Balcilar*, Rangan Gupta ${ }^{* *}$, Chien-Chiang Lee ${ }^{* * *}$, and Godwin Olasehinde-Williams ${ }^{* * * *}$

* Department of Economics, Eastern Mediterranean University, Famagusta, via Mersin 10, Northern Cyprus, Turkey; Department of Economics, University of Pretoria, Pretoria, 0002, South Africa; Montpellier Business School, Montpellier, France. Email: mehmet@ mbalcilar.net.

*** Department of Economics, University of Pretoria, Pretoria, 0002, South Africa. Email: rangan.gupta@up.ac.za.

**** Corresponding author. Department of Finance, National Sun Yat-sen University, Kaohsiung, Taiwan. Email: cclee@cm.nsysu.edu.tw.

**** Department of Economics, Eastern Mediterranean University, Famagusta, via Mersin 10, Northern Cyprus, Turkey. Email: alanisey@gmail.com. 


\title{
Highlights
}

-We evaluate the synergistic effect of financial sectors on economic growth in African countries.

- The insurance-banking-growth nexus is examined through bootstrap panel causality tests.

- The relationship between insurance and banking is a complimentary one and their synergistic impact on growth is positive.

- The feedback hypothesis is confirmed in the relationship between finance and growth.

\begin{abstract}
It is widely understood that the insurance and banking sectors of every economy perform some functions in driving economic growth. What is not yet well documented is whether their roles are complimentary or substitutive. With the aid of the dynamic panel-GMM estimation technique, this paper evaluates the synergistic effect of both sectors on economic growth in a panel of 11 African countries that are responsible for most of the activities in the continent's financial sector. The insurance-banking-growth nexus was also examined through panel causality tests. The results show that life insurance market and the banking sector are complimentary and that the non-life insurance market and the banking sector are also complimentary. We find that overall, the relationship between the insurance and banking sectors in Africa is a complimentary one and that their synergistic impact on economic growth is positive. The feedback hypothesis was also confirmed in the relationship between the insurance sector and economic growth and between the banking sector and economic growth.
\end{abstract}

Keywords: Synergistic effect, Insurance market, Banking sector, Africa, Dynamic GMM, Panel Granger causality JEL Codes: C33, G21, G22 


\section{Introduction}

Explaining why economic growth rates differ among countries is one of the central focus areas in growth economics. Many factors such as education, macroeconomic stability, trade openness, capital accumulation, quality of institutions and resource endowments have been established as being partly responsible for these differences (Romer, 1986; Lucas, 1988; Barro, 1991; Rebelo, 1991; Mankiw et al., 1992; Grossman and Helpman, 1993; Acemoglu, 1996). More recently, the level of financial sector development has also been added to the list of factors causing these differences (King and Levine, 1993a, 1993b; Demetriades and Hussein, 1996; Levine, 1997; Demirgüç-Kunt and Maksimovic, 1998; Rajan and Zingales, 1998).

Following the ground-breaking works of authors like Schumpeter (1934), Robinson (1952), Goldsmith (1969), McKinnon (1973), and Shaw (1973), many researchers have explored the connection between financial market activities and economic growth. Empirical evidence provided by most of these researchers is heavily skewed in favor of positive impacts of financial market activities on economic growth (see Levine et al., 2000; Beck and Levine, 2004; Beck et al., 2005; Loayza and Ranciere, 2006; Cheng and Degryse, 2010). The summary of these studies is that the financial sector boosts economic growth through its roles of mobilizing savings, efficiently allocating resources, aiding the trading, hedging, pooling and diversification of risks, exertion of corporate control etc.

The most common approach used by previous studies of the relationship between financial market activities and growth is the examination of one-way independent impacts of financial markets on economic growth (Ang, 2008; Haiss and Sümegi, 2008; Körner and Schnabel, 2009; Bojanic, 2012). Other researchers have gone further to investigate the bi-directional interactions between specific financial markets and economic growth (Al-Yousif, 2002; Kugler and Ofoghi, 2005; Wolde-Rufael, 2009).

While these two approaches have succeeded in providing relatively meaningful findings in the past, their adequacy in recent times has waned. The reason for this is two-fold. First, the financial sector has become extremely complex over the past few decades such that separation between different financial markets has made unclear their individual contributions to the economy (Pradhan et al., 2017). The second is that various financial markets in the financial system exhibit 
complex inter-relations amongst themselves (Tennant and Abdulkadri, 2010; Lee, 2013; Liu et al., 2016). Moreover, it has been shown that the insurance sector in particular has the potential to stimulate economic growth through its interaction with banking sector activities (Chen et al., 2012; Lee, 2013).

Thus, the motivations behind this study are as follows; first, rather than study only the independent relationships between specific financial markets and economic growth, we improve on previous studies by examining both the independent and synergistic effects of the insurance and banking sectors on economic growth. This approach provides an additional channel for investigating the financial sector-economic growth nexus. Our focus is on the insurance and banking sectors, being two key components of the financial system. To the best of our knowledge, this study is the first to empirically investigate the synergistic impact of the insurance and banking sectors on the economic performance of Africa.

Second, to avoid the pre-test bias associated with pretesting for stationarity and cointegration, and the estimation bias associated with the possible presence of cross-sectional dependence, we carry out the panel Granger causality tests using the approach in Emirmahmutoglu and Kose (2011) as a form of robustness check and also as a means of detecting the direction of causality in the insurance-banking-growth nexus. The direction, strength, and stability of the linkage among banking sector, insurance market and economic growth play a critical role in the implementation of economic and financial polices (Lee, 2013). To the best of our knowledge, this approach has not been considered in examining the relationships between insurance, banking and economic growth.

In summary, our findings show that life insurance market activities, non-life insurance market activities and banking sector activities individually stimulate economic growth. Moreover, life insurance market activities and banking sector activities have complementary synergistic effects on economic growth in Africa and similarly, non-life insurance market activities and banking sector activities also have complementary synergistic effects on economic growth in Africa. The insurance and banking sectors function better together than they do separately in the continent. Improvements in the insurance sector (banking sector) does not only lead to better economic performance but also to a better banking sector (insurance sector) performance. We also were able 
to confirm the feedback hypothesis for the relationship between the insurance sector and economic growth, and the relationship between the banking sector and economic growth along the line.

The rest of this article is structured as follows: Section 2 presents a review of relevant literature and the identified gap. Section 3 details the conceptual framework and the proposed hypotheses. Section 4 describes the specified model and data used in the study. Section 5 outlines the empirical methodology adopted in the study. Section 6 presents obtained results and their interpretations, and in Section 7, the important conclusions are presented.

\subsection{An overview of the financial sector in Africa}

With a few exceptions like South Africa and Mauritius, the financial sectors across most of Africa are still mostly underdeveloped. A close look at the insurance market in Africa however shows that the continent's economic boom and the resultant growth of its insurance market, which well exceeds the global average, are the region's most significant strengths (KPMG, 2015). The continent's biggest opportunities for further growth in the insurance market lie in the very low insurance penetration (Africa's average insurance penetration of $2.8 \%$ is well below the global average of $6.1 \%$ in 2016), introduction of new products (in life insurance, medical care and micro-insurance) and a growing middle class (African Insurance Organisation (AIO), 2016).

Despite the positives, Africa's insurance markets remain diverse and fragmented, with only 10 African countries (South Africa, Morocco, Egypt, Nigeria, Kenya, Algeria, Angola, Namibia, Tunisia and Mauritius) contributing 92\% of the total premiums based on 2014 figures, and South Africa alone accounting for $87 \%$ and $40 \%$ of life and non-life premiums, respectively (African Insurance Organisation (AIO), 2016). A shortage of skilled insurance professionals, low incomes and a lack of understanding of insurance benefits by the populace are some of the reasons for the poor performance of the insurance markets across the continent. 
Fig. 1, Fig. 2 show the geographical split of total insurance premiums across Africa in 2016. The 10 aforementioned countries jointly account for $91 \%$ of total premiums in the continent and when the South African insurance market is excluded, the remaining 9 countries jointly account for $70 \%$ of total premiums.

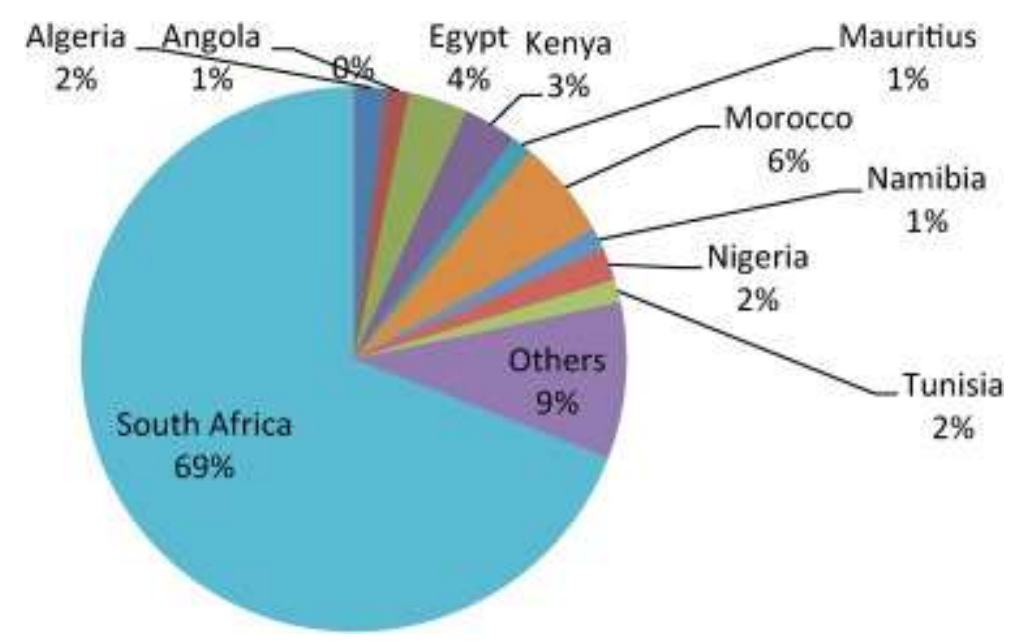

Fig. 1. Geographical split of African insurance premiums.

Data from Swiss Re Sigma Explorer (2016)

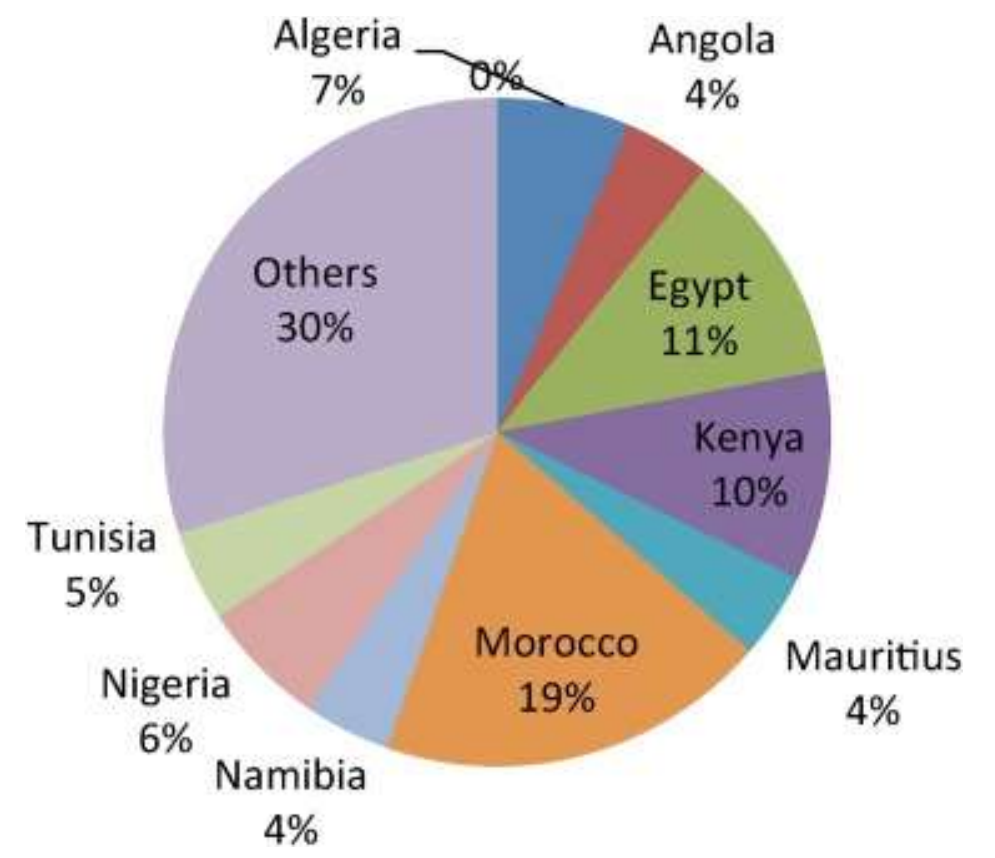

Fig. 2. Geographical split of African insurance premiums (excluding South Africa).

Data from Swiss Re Sigma Explorer (2016) 
Like the insurance sector, the banking sectors of several African countries have exhibited significant growth in recent times mainly due to economic growth, better regulatory oversight and the rapid rise of Pan-African bank (KPMG, 2015). The growing presence of large global and Pan-African banks across the continent has not only improved the quality and availability of financial services but has also driven efficiency, innovation and financial deepening. Despite the strong growth being witnessed in the banking sector, penetration is still well below the global average and remains as low as $36 \%$ in some of the larger African economies (KPMG, 2015). As shown in Fig. 3, the same set of countries identified as dominant players in the African insurance market also jointly account for $61 \%$ of the top 200 African banks in terms of total assets, net earnings, credits and deposits in 2014.

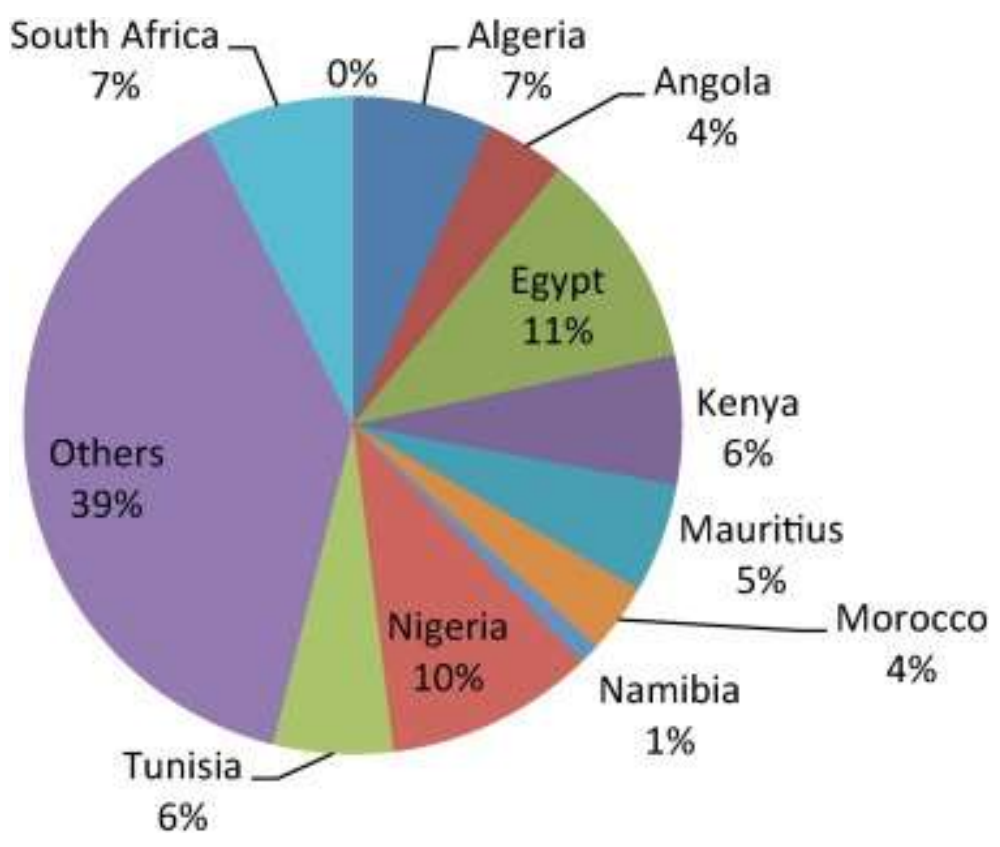

Fig. 3. Geographical split of top 200 banks in Africa.

Data from the Africa Report (2014) 


\section{Literature Review}

The extensive body of literature on the relationship between financial markets, economic growth, and insurance market activity are broadly grouped into 4 categories (Pradhan et al., 2013, 2017; Samargandi et al., 2015).

The first category consists of those who provide empirical evidence in support of the supplyleading theory. This theory claims that economic growth is preceded by financial development. The rationale behind this approach is that financial development induces improvements in savings and investment efficiency which in turn drives economic growth. Examples of such studies include Ward and Zurbruegg (2000), Haiss and Sümegi (2008), Han et al. (2010), Chen et al. (2012), Pan and Su (2012), Pradhan et al. (2015), who all find one-way positive effect of insurance market activity on growth performance, thus confirming the supply-leading theory in the relationship between insurance market activity and economic growth.

Similarly, studies by Calderón and Liu (2003), Ang (2008), Körner and Schnabel (2009), Bojanic (2012), Pradhan, Tripathy et al. (2014) all find one-way effect of banking sector activity on economic growth, providing evidence in support of the supply-leading theory in the banking sector.

The second category is made up of supporters of the demand-following theory. This theory suggests that economic growth drives the demand for financial services. The underlying idea is that growth in the real sector of the economy leads to increased need for supporting financial services and this consequently induces growth in the financial sector. Studies by Beenstock et al. (1988), Outreville (1990), Browne and Kim (1993), Beck and Webb (2003), Ching et al. (2010), Pradhan et al. (2014) all find evidence in support of a one-way impact of economic growth on insurance market activity, confirming the demand-following theory in the relationship between insurance market activity and economic growth. Also, studies by Liang and Jian-Zhou (2006), Ang and McKibbin (2007), and Panopoulou (2009) confirm the demand-following theory by providing evidence in support of one-way impact of economic growth on banking sector activities.

The third category of studies consists of those who affirm the neutrality hypothesis. This group of literature argues that there is no significant relationship between financial market activities and 
economic growth. Examples include Pan and Su (2012), Pradhan et al. (2015) who find no relationship between insurance market activity and economic growth, and Al-Yousif (2002), Mukhopadhyay et al. (2011) who find no relationship between banking sector activity and economic growth.

The fourth category covers the group of studies that infer bi-directional causality between financial markets and economic growth. This is referred to as the feedback hypothesis. This group of studies supports both the supply-leading and demand-following theories. Their position is that improved financial sector performance positively affects economic growth; this increased growth in turn further stimulates increased demand for financial services. Such studies include Kugler and Ofoghi (2005), and Pradhan et al. (2016) who find bi-directional causality between insurance market activity and economic growth, while Al-Yousif (2002), Wolde-Rufael (2009), and Pradhan et al. (2013) find bi-directional causality between banking sector activity and economic growth.

Over and beyond the investigation of financial sector-economic growth nexus, researchers have also studied the interactions between different financial markets. Researchers have particularly studied the interaction between insurance market activities and banking sector activities and obtained mixed results. Some have found complimentary effects in the interaction between the insurance and banking sectors (see Webb et al., 2002; Zou and Adams, 2006; Bernoth and Pick, 2011; Lee and Chang, 2015). The complementary effects are said to be due to the risk mitigating and compensating activities of the insurance sector which protects lenders and encourages banks to easily offer more loans.

Some others have found substitutive interactions between both markets (see Levine, 1997; Tennant and Abdulkadri, 2010). The substitutive impact is viewed to be due to the duplicative role of both the insurance and banking sectors in capital allocation. The insurance sector to some degree also plays the role of an intermediary in the transfer of savings which is the traditional role of the banking credit market (Liu and Zhang, 2016). Song and Thakor (2010) further discovered that the relationship between the two markets could be both complimentary and substitutive under certain conditions. 


\subsection{Identified gap in literature}

The detailed overview of relevant literature on the relationship between the financial sector and economic growth provided in section 2 clearly shows that the individual impacts of the insurance and banking sectors, as well as the interaction between the insurance sector and the banking sector have been studied extensively. The synergistic effect of both sectors on economic growth is where the main gap in the financial sector-economic growth literature exists.

\section{Hypotheses}

We propose a conceptual framework for evaluating the individual and interactive relationships between insurance market activities and banking sector activities on economic growth in Africa. These relationships are tested through the null $\left(\mathrm{H}_{0}\right)$ hypotheses and alternative $\left(\mathrm{H}_{1}\right)$ hypotheses specified below and described in Figure 4.

$\mathrm{H}_{0}^{\mathrm{A}}$ : Insurance market activities do not influence economic growth.

$\mathrm{H}_{1}^{\mathrm{A}}$ : Insurance market activities exert some level of influence economic growth.

$\mathrm{H}_{0}^{B}$ : Banking sector activities do not influence economic growth.

$\mathrm{H}_{1}^{\mathrm{B}}$ : Banking sector activities exert some level of influence economic growth.

$\mathrm{H}_{0}^{\mathrm{C}}$ : The interaction between Insurance market and banking sector activities does not influence economic growth.

$\mathrm{H}_{1}^{\mathrm{C}}$ : The interaction between Insurance market and banking sector activities exerts some level of influence economic growth. 


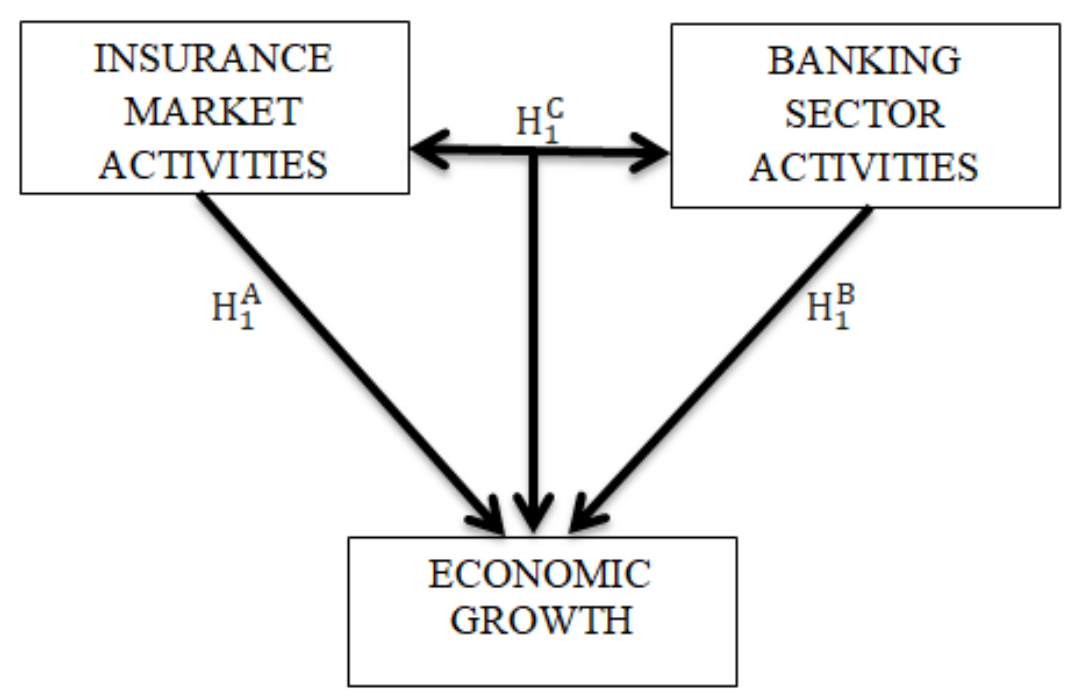

Figure 4. Conceptual framework with hypotheses

\section{Model specification}

This paper applies panel data analysis to examine the synergistic impacts of insurance market activity and banking sector market activities on economic growth in Africa. The basic regression model is:

$y_{i t}=\alpha y_{i t-1}+\beta^{\prime} x_{i t}+v_{i t}, \quad v_{i t}=\mu_{i}+\eta_{t}+\varepsilon_{i t}$

where $y_{i t}$ is real gross domestic product, the dependent variable, in country $i$ at time $t, \beta$ represents a vector of coefficients, and $x_{i t}$ represents the regressors for each country $i$ at time $t$; it includes (i) measures of insurance market activity and banking sector market activity and their interactions, (ii) variables included to control for additional factors that could influence economic growth in the selected countries such as inflation rates, government expenditure, total investment, trade openness and initial GDP. $\mu_{i}$ represents the unobserved country-specific effects. $\eta_{t}$ represents the time specific effects and $\varepsilon_{i t}$ represents the idiosyncratic error term.

We specifically determine the synergistic effects of the insurance and banking sector market activities on economic growth in Africa with the aid of interaction terms between life insurance market activity and banking sector activity, non-life insurance market activity and banking sector activity and between total insurance market activity and banking sector activity. 


\section{Methodology}

\subsection{Data}

To determine the synergistic impact of insurance and banking sector market activities on Africa's economic growth, we construct a panel time-series data set by employing yearly data on measures of insurance market activities and banking sector market activities. The data set encompasses the 11 selected African countries (Algeria, Angola, Botswana, Egypt, Kenya, Mauritius, Morocco, Namibia, Nigeria, South Africa, and Tunisia) that are responsible for most of the activities in Africa's financial sector. The data set covers the period from 1995 to 2016.

There are 2 popularly used measures of insurance market activity—insurance density (the ratio of total insurance premiums to total population) and insurance penetration (the ratio of total insurance premiums to GDP). Although both measures are relatively similar, differing only by the denominator, we adopt insurance density as the measure of insurance market activity mainly because per capita figures are relatively insensitive to territorial changes and control for the scale of the economy (Chang et al., 2013). Moreover, the insurance industry can be broadly divided into life and non-life insurance markets. We thus employ measures of life insurance market activity (life insurance density) and non-life insurance market activity (non-life insurance density) as well as an aggregate of both (total insurance density). Data on insurance density (life, non-life and total) were obtained from the Sigma reports of the Swiss Reinsurance Company.

Banking sector activity has mostly been measured with variables such as banking sector domestic credit in past studies. However, such measures do not take factors such as the quality of financial services, financial sector efficiency and stability into consideration. Banking sectors have evolved over time and have become multifaceted. Large banking sectors are of little use if they are not accessible to a large percentage of economic agents. Also, the contribution of banking sectors to economic growth across Africa would be insignificant if they lack depth or are inefficient. Banking sectors may even negatively impact the economy if they are unstable. We thus adopt the global financial development variables provided by the World Bank. The database can be accessed at http://www.worldbank.org/en/publication/gfdr/data/global-financial-development-database. It provides measures for financial development on the basis of financial access, financial depth, financial efficiency and financial stability. Of the numerous measures provided on each of these 4 
categories, we specifically select bank accounts per 1000 adults as the measure for banking access, private credit by deposit money banks to GDP as the measure of banking sector depth, the bank lending-deposit spread as the measure of banking sector efficiency and the bank Z-score as the measure of banking sector stability.

To guide against the problem of multicollinearity that may arise from modeling these four different measures of banking sector activities in the same equation, or the possible shortcomings that could arise from using just one of them, we create a composite index of banking sector activity (BSA) from the 4 different measures.

The composite indices are constructed via Principal Component Analysis (PCA). With PCA we are able to convert the original individual measures into linear combinations that account for relatively large proportion of the variance in the original measures (Pradhan et al., 2014). It is formulated thus:

$p_{i}=\sum_{i=1}^{n} a_{i j} x_{i}$

where $p_{i}, i=1,2, \ldots, k$, are principal components, $a_{i j}$ are component loadings and $x_{i}$ are the original measures.

The PCA procedure includes the following steps: generation of a detail matrix, construction of standardized variables, obtaining a correlation matrix, determination of eigenvalues and eigenvectors and determination of principal components (Hosseini and Kaneko, 2011, 2012). To control for differences in units of measurements, we use the various insurance and banking activity measures in their standardized forms. Each composite index is thereafter constructed using the formula:

$C I=\sum_{i=1}^{n} a_{i j} \frac{x_{i j}}{\sigma(x)_{i}}$

where $\mathrm{CI}$ is composite index (BSA) and $\sigma$ is standard deviation.

Other variables used in our estimations are economic growth (dependent variable), inflation, government expenditure, total investment, trade openness and lag of real GDP (control variables). Data on GDP, trade openness and inflation was taken from the World Development 
Indicator (http://data.worldbank.org), and data on government expenditure and total investment was obtained from the World Economic Outlook database (https://www.imf.org). Table 1 provides a detailed description of the variables.

Table 1. Variables and their definitions

\begin{tabular}{ll}
\hline Variables & Definition \\
\hline GDP & $\begin{array}{l}\text { Gross domestic product in logarithms, with the rate of economic growth measured as percentage } \\
\text { change ( } \Delta \text { GDP) }\end{array}$ \\
LGDP ${ }_{-1}$ & $\begin{array}{l}\text { Initial gross domestic product (GDP in dollars of the previous year) in logarithmic form, to } \\
\text { capture convergence effect }\end{array}$ \\
LIMA & Composite index of life insurance market activity \\
NIMA & Composite index of non- life insurance market activity \\
TIMA & Composite index of total insurance market activity \\
BSA & Composite index of banking sector activity \\
LIMA*BSA & Interaction between life insurance market activity and banking sector activity \\
NIMA*BSA & Interaction between non-life insurance market activity and banking sector activity \\
TIMA*BSA & Interaction between total insurance market activity and banking sector activity \\
INF & $\begin{array}{l}\text { Inflation rate measured as percentage change in consumer price index } \\
\text { Government expenditure measured as total expense and the net acquisition of nonfinancial }\end{array}$ \\
GEXP & $\begin{array}{l}\text { assets as } \% \text { of GDP } \\
\text { Total investment measured as gross fixed capital formation, changes in inventories and } \\
\text { acquisitions }\end{array}$ \\
TRADE & Trade openness measured as Exports + imports as \% of GDP \\
\hline
\end{tabular}

\subsection{Estimation technique}

\subsubsection{Dynamic panel GMM}

The inter-relations between financial markets and economic growth have been extensively studied using generalized method of moments (GMM) estimators for dynamic panel data (Anderson and Hsiao, 1981; Arellano and Bond, 1991; Arellano and Bover, 1995; Blundell and Bond, 1998; Zhang et al., 2012). The GMM technique is regarded as superior to the traditional OLS estimation technique for studying financial variables (Driffill et al., 1998). Furthermore, according to Baum (2006), the GMM estimator is the most appropriate for studying dynamic panel models. It is particularly useful under these conditions; when one or more of the explanatory variables contain lagged values of the dependent variable, when the model suffers from endogeneity bias, and when serial correlation and (or) heteroscedasticity are present within the cross-sections (Roodman, 
2006). It is also suitable for short macro panels (Lee and Hsieh, 2013). Other advantages of GMM include its ability to control for time and country specific effects, freedom to use lags of variables in the model as instruments.

We likewise adopt the panel-GMM estimation technique for two key reasons; first, because our regression equation includes lagged GDP as an explanatory variable, making it a dynamic model and second, because of the possibility of endogeneity bias due to simultaneous causality between financial market activities and economic growth.

There are two commonly used GMM estimators, the difference-GMM estimator (Arellano and Bond, 1991) which transforms data by subtracting past observations from current observations:

$\Delta y_{i t}=\alpha \Delta y_{i t-1}+\beta^{\prime} \Delta x_{i t}+\Delta v_{i t}$

And the system-GMM estimator (Arellano and Bover, 1995; Blundell and Bond, 1998) which transforms data by subtracting the mean of all future observations from the current observation (forward orthogonal deviations):

$W_{i t+1} \equiv C_{i t}\left[W_{i t}-\frac{1}{T_{i t}} \sum_{S>t} W_{i s}\right]$

We adopt the system-GMM estimator because of its improved efficiency gains over the firstdifference estimator (see Baltagi, 2008). We also employ the two-step variant of the GMMestimator since it is more efficient than the one-step variant in the system-GMM.

The instrumental variables employed are the first and second lags of all explanatory variables. The Sargan test of over-identifying restrictions is used to test the overall validity of the instruments. Our choice of Sargan statistics instead of the Hansen $J$ tests is first because Sargan statistics are not vulnerable to instrument proliferation as they are not dependent on the optimal weighting matrix estimate (Roodman, 2009), and second, because it has been consistently found that the Sargan test tends to be more conservative than the Hansen test which easily produces $J$ statistics with implausibly perfect $p$-values of 1.000 (Zhang et al., 2012). The Arellano-Bond AR(2) statistics are computed to detect the presence of autocorrelation in the error terms. 


\subsubsection{Bootstrap panel Granger causality}

Additional evidence on the interaction between insurance sector activities, banking sector activities and economic growth is provided by carrying out the Emirmahmutoglu and Kose (2011) panel causality test with bootstrapping. This test is the most suitable for our study since it does not require stationarity for all the series in the underlying VAR system and may be applied to panels comprising of stationary, non-stationary, cointegrated and non-cointegrated series (Seyoum et al., 2014). The test is also valid in the presence of cross-sectional dependence.

Emirmahmutoglu and Kose (2011) show that the Fisher (1932) test statistic may be used to test for panel Granger non-causality and specified thus:

$\lambda=-2 \sum_{i=1}^{N} \ln _{(p i)} i=1,2, \ldots, N$.

$p i$ represents the $\mathrm{p}$ value for the $i$ th cross section and the test statistic has a chi-square distribution with $2 \mathrm{~N}$ degrees of freedom.

Following Emirmahmutoglu and Kose (2011), we adopt the lag augmented VAR (LA-VAR hereafter) model with $\mathrm{L}_{\mathrm{y}}+\mathrm{dmax}_{\mathrm{i}}$ lags in heterogeneous mixed panels. It is specified as follows:

$$
\begin{aligned}
& B S A_{i t}=a_{1 i}^{B S A}+\sum_{j=1}^{L_{B S A}+\operatorname{dmax}_{i}} B_{1 i j} B S A_{i t-j}+\sum_{j=1}^{L_{L I M A}+\operatorname{dmax}_{i}} \gamma_{1 i j} L I M A_{i t-j}+\varepsilon_{1 i t} \\
& L I M A_{i t}=a_{2 i}^{L I M A}+\sum_{j=1}^{L_{B S A}+\operatorname{dmax}_{i}} B_{2 i j} B S A_{i t-j}+\sum_{j=1}^{L_{L I M A}+d m a x_{i}} \gamma_{2 i j} L I M A_{i t-j}+\varepsilon_{2 i t} \\
& B S A_{i t}=a_{1 i}^{B S A}+\sum_{j=1}^{L_{B S A}+\operatorname{dmax}_{i}} B_{1 i j} B S A_{i t-j}+\sum_{j=1}^{L_{N I M A}+\operatorname{dmax}_{i}} \gamma_{1 i j} N I M A_{i t-j}+\varepsilon_{1 i t} \\
& N I M A_{i t}=a_{2 i}^{N I M A}+\sum_{j=1}^{L_{B S A}+\operatorname{dmax}_{i}} B_{2 i j} B S A_{i t-j}+\sum_{j=1}^{L_{N I M A}+\operatorname{dmax}_{i}} \gamma_{2 i j} N I M A_{i t-j}+\varepsilon_{2 i t} \\
& B S A_{i t}=a_{1 i}^{B S A}+\sum_{j=1}^{L_{B S A}+\operatorname{dmax}_{i}} B_{1 i j} B S A_{i t-j}+\sum_{j=1}^{L_{T I M A}+\operatorname{dmax}_{i}} \gamma_{1 i j} T I M A_{i t-j}+\varepsilon_{1 i t} \\
& T I M A_{i t}=a_{2 i}^{T I M A}+\sum_{j=1}^{L_{B S A}+\operatorname{dmax}_{i}} B_{2 i j} B S A_{i t-j}+\sum_{j=1}^{L_{T I M A}+\operatorname{dmax}_{i}} \gamma_{2 i j} T_{I M A_{i t-j}+\varepsilon_{2 i t}}
\end{aligned}
$$

The null hypothesis for each pair of bivariate Granger causality tests are:

$$
H_{0}: \gamma_{1 i 1}=\gamma_{1 i 2}=\cdots=\gamma_{1 i k_{i}}=0 \text { for } i=1,2, \ldots, N
$$




$$
H_{0}: \beta_{2 i 1}=\beta_{2 i 2}=\cdots=\beta_{2 i k_{i}}=0 \text { for } i=1,2, \ldots, N
$$

\section{Results}

The panel system GMM regression outcomes are reported in Table 2. The table displays the results of three estimations, the first estimation (M1) includes life insurance market activity index (LIMA) and its interaction with banking sector activity (BSA). The second estimation (M2) includes nonlife insurance market activity index (NIMA) and its interaction with banking sector activity (BSA). The third estimation (M3) contains total insurance market activity index (TIMA) and its interaction with banking sector activity index (BSA). The estimation results provide insight into the individual and joint impacts of insurance market activity and banking sector activity on economic growth.

With respect to the financial variables, the three banking sector activity indices are positive, although only two are statistically significant (5.929 and 3.927 in columns M1 and M3 respectively). This confirms that the banking sector on its own is a driver of economic growth. Life insurance market activity, non-life insurance market activity and total insurance market activity all have positive coefficients (9.181, 2.492 and 22.475). However, while life and non-life insurance market activity coefficients are significant, that of total insurance market activity is insignificant. We may thus conclude that the insurance sector on its own drives economic growth.

With respect to the interaction terms, column M1 indicates that the interaction between BSA and LIMA is positive and significant. It can be expressed mathematically as:

$\frac{\Delta y_{i t}}{\Delta L I M A_{i t}}=9.181+9.189 B S A$ or $\frac{\Delta y_{i t}}{\Delta B S A_{i t}}=5.929+9.189$ LIMA

Our inference from these results is that (i) the more developed the banking sector activity, the higher the point estimate of the effect of life insurance market activity on economic growth and (ii) the more developed the insurance market activity, the higher the point estimate of the effect of banking sector activity on economic growth. Column M2 indicates that the interaction between BSA and NIMA is positive and significant. The mathematical representation is:

$$
\frac{\Delta y_{i t}}{\Delta N I M A_{i t}}=2.492+1.830 B S A \text { or } \frac{\Delta y_{i t}}{\Delta B S A_{i t}}=0.016+1.830 N I M A
$$


Table 2. Dynamic panel GMM estimation results

\begin{tabular}{|c|c|c|c|}
\hline Variables & M1 & M2 & M3 \\
\hline BSA & $\begin{array}{l}5.929^{* * *} \\
(2.243)\end{array}$ & $\begin{array}{l}0.016 \\
(0.757)\end{array}$ & $\begin{array}{l}3.927^{* * *} \\
(0.572)\end{array}$ \\
\hline LIMA & $\begin{array}{l}9.181^{\text {*** }} \\
(2.714)\end{array}$ & & \\
\hline NIMA & & $\begin{array}{l}2.492^{* * *} \\
(0.731)\end{array}$ & \\
\hline TIMA & & & $\begin{array}{l}22.475 \\
(17.094)\end{array}$ \\
\hline \multicolumn{4}{|l|}{ Interactions } \\
\hline BSA*LIMA & $\begin{array}{l}9.189^{*} \\
(4.809)\end{array}$ & & \\
\hline BSA*NIMA & & $\begin{array}{l}1.830^{* * *} \\
(.139)\end{array}$ & \\
\hline BSA*TIMA & & & $\begin{array}{l}14.734^{*} \\
(8.187)\end{array}$ \\
\hline \multicolumn{4}{|l|}{ Control variables } \\
\hline LGDP-1 & $\begin{array}{l}-12.221^{\text {*** }} \\
(4.239)\end{array}$ & $\begin{array}{l}-13.405^{* * *} \\
(3.106)\end{array}$ & $\begin{array}{l}-13.719^{* *} \\
(6.561)\end{array}$ \\
\hline INF & $\begin{array}{l}-0.221^{*} \\
(0.132)\end{array}$ & $\begin{array}{l}-0.128^{* * *} \\
(0.022)\end{array}$ & $\begin{array}{l}-0.097^{* * *} \\
(0.016)\end{array}$ \\
\hline GEXP & $\begin{array}{l}0.779 \\
(0.766)\end{array}$ & $\begin{array}{l}-0.228 \\
(0.266)\end{array}$ & $\begin{array}{l}-0.504 \\
(0.430)\end{array}$ \\
\hline INV & $\begin{array}{l}0.415^{* *} \\
(0.235)\end{array}$ & $\begin{array}{l}0.282^{*} \\
(0.193)\end{array}$ & $\begin{array}{l}0.623^{\text {** }} \\
(0.303)\end{array}$ \\
\hline TRADE & $\begin{array}{l}0.331^{* * *} \\
(0.060)\end{array}$ & $\begin{array}{l}0.507^{* * *} \\
(0.042)\end{array}$ & $\begin{array}{l}0.086 \\
(0.080)\end{array}$ \\
\hline Countries & 11 & 11 & 11 \\
\hline Observations & 158 & 158 & 158 \\
\hline Specification tests & & & \\
\hline Sargan test statistic & 3.410 & 3.184 & 3.396 \\
\hline P-value of Sargan test stat & 0.333 & 0.364 & 0.335 \\
\hline $\mathrm{AR}(1)$ test statistic & -0.719 & 0.105 & -0.514 \\
\hline P-value of $\mathrm{AR}(1)$ test stat & 0.472 & 0.916 & 0.607 \\
\hline $\operatorname{AR}(2)$ test statistic & -0.916 & -0.329 & 0.412 \\
\hline P-value of $\mathrm{AR}(2)$ test stat & 0.359 & 0.742 & 0.680 \\
\hline
\end{tabular}

Notes: (1) *,** and *** mean statistic relationship significant at $10 \%, 5 \%, 1 \%$, respectively; (2) M1, M2 and M3 represent the regression models (1), (2)and (3), respectively (3)Standard errors of the corresponding coefficients are shown in parentheses. 
Again, we infer that the more developed the banking sector activity (non-life insurance market activity), the higher the point estimate of the effect of non-life insurance market activity (banking sector activity) on economic growth.

Finally, the positive interaction between BSA and TIMA in column M3 (14.734) confirms that the complimentary pattern of relationships discovered is true overall.

With respect to the control variables, the coefficients of initial GDP are negative and significant in all three estimations (-12.221, -13.405 and -13.719 in columns M1, M2 and M3 respectively). This provides evidence in support of the convergence theory which claims that higher levels of initial income are associated with relatively lower levels of growth. All three coefficients of inflation are negative and significant $(-0.221,-0.128$ and -0.097 in columns M1, M2 and M3 respectively). This confirms that inflation negatively influences economic growth. All three coefficients of investment are positive and significant $(0.414,0.282,0.623$ in columns M1, M2, M3 respectively). We thus affirm that investment positively impacts economic growth. While the three coefficients for trade are positive, only two (0.331 and 0.507 in columns M1 and M2 respectively) are statistically significant. Our conclusion is that trade openness supports economic growth. All the coefficients for government expenditure turned out insignificant, it is thus impossible to reach a conclusion on its impact on economic growth based on our estimations.

The Sargan test results indicate that the validity of the instruments used in our estimations cannot be rejected. Also, all three estimations pass the second order autocorrelation test. The test results indicate that the absence of serial correlation in the error terms cannot be rejected.

The panel causality test results for the interaction between insurance market activity, banking sector activity and economic growth are presented in Table 3.

The null that BSA does not Granger cause GDP and the null that GDP does not Granger cause BSA are both rejected at $1 \%$ significance level. We conclude that the relationship between both variables is bi-directional. This finding confirms the influence of banking sector activities on economic growth and lends credence to the feedback hypothesis in the banking sector. 
Table 3. Results from Emirmahmutoglu-Kose Granger causality tests

\begin{tabular}{llll}
\hline Hypothesis & Statistic & P-Value & Conclusion \\
\hline BSA $\rightarrow$ LIMA & $63.875^{* * *}$ & 0.000 & Two way causality between BSA and LIMA \\
LIMA $\rightarrow$ BSA & $73.828^{* * *}$ & 0.000 & \\
BSA $\rightarrow$ NIMA & $145.328^{* * *}$ & 0.000 & Two way causality between BSA and NIMA \\
NIMA $\rightarrow$ BSA & $74.467^{* * *}$ & 0.000 & \\
BSA $\rightarrow$ TIMA & $42.019^{* * *}$ & 0.006 & Two way causality between BSA and TIMA \\
TIMA $\rightarrow$ BSA & $81.150^{* * *}$ & 0.000 & \\
BSA $\rightarrow$ GDP & $79.612^{* * *}$ & 0.000 & Two way causality between BSA and INF \\
GDP $\rightarrow$ BSA & $68.591^{* * *}$ & 0.000 & \\
LIMA $\rightarrow$ GDP & $77.566^{* * *}$ & 0.000 & Two way causality between LIMA and GDP \\
GDP $\rightarrow$ LIMA & $72.192^{* * *}$ & 0.000 & \\
NIMA $\rightarrow$ GDP & $78.666^{* * *}$ & 0.000 & Two way causality between NIMA and GDP \\
GDP $\rightarrow$ NIMA & $99.864^{* * *}$ & 0.000 & \\
TIMA $\rightarrow$ GDP & $89.074^{* * *}$ & 0.000 & Two way causality between TIMA and GDP \\
GDP $\rightarrow$ TIMA & $189.845^{* * *}$ & 0.000 & \\
BSA $\rightarrow$ GDP & $163.974^{* * *}$ & 0.000 & Two way causality between BSA and GDP \\
GDP $\rightarrow$ BSA & $162.783^{* * *}$ & 0.000 & \\
\hline Ftes $(1) * * * a p$ &
\end{tabular}

Notes: (1)*,** and *** mean statistic relationship significant at 10\%, 5\%, 1\%, respectively; (2) reported statistics are the Wald statistics.

The null that LIMA does not Granger cause GDP and the null that GDP does not Granger cause LIMA are both rejected at $1 \%$ significance level. The null that NIMA does not Granger cause GDP and the null that GDP does not Granger cause NIMA are both rejected at $1 \%$ significance level. The null that TIMA does not Granger cause GDP and the null that GDP does not Granger cause TIMA are both rejected at $1 \%$ significance level. The bidirectional causality found between the insurance market activity (either aggregated or disaggregated) and GDP confirms that the insurance sector exerts some influence on economic growth. The results also confirm that the feedback hypothesis holds in the insurance sector.

The null that BSA does not Granger cause LIMA and the null that LIMA does not Granger cause BSA are both rejected at $1 \%$ significance level. The null that BSA does not Granger cause NIMA and the null that NIMA does not Granger cause BSA are both rejected at $1 \%$ significance level. The null that BSA does not Granger cause TIMA and the null that TIMA does not Granger cause BSA are both rejected at $1 \%$ significance level. We thus conclude that the relationship between the banking sector and insurance sector (aggregated or disaggregated) is bi-directional. This provides further evidence that there is a strong interaction between these two sectors. 


\section{Conclusion}

In this paper, we examined the synergistic impact of insurance market activity and banking sector activity on economic growth of Africa using a dynamic panel data model. Our findings show that both of them have statistically significant positive individual effects on economic growth. Moreover, the interaction effects confirm that both insurance and banking sector activities have a complementary synergistic effect on economic growth. We find that both the insurance and banking sector function better together than separately. Improvements in the insurance sector (banking sector) does not only lead to better economic performance but also to a better banking sector (insurance sector) performance.

We further tested for interactions among the insurance sector, the banking sector and economic growth through panel causality tests and found that a positive bi-causal relationship exists between insurance market activities and banking sector activities. This further confirms the complementary nature of their interaction and supports the findings of Webb et al. (2002), Zou and Adams (2006), Bernoth and Pick (2011), and Lee and Chang (2015). The panel causality tests also showed that bidirectional causality exists between insurance market activities and economic growth, and between banking sector activities and economic growth.

We therefore conclude and recommend as follows; first, since the relationship between the insurance sector and the banking sector is complementary, policies that reinforce the complementary relationship between both sectors and neutralize the possible substitutive relationship that could occur between them should be actively pursued.

Second, since the feedback hypothesis is confirmed between the insurance sector and economic growth we suggest that the insurance sector's risk mitigating and compensating actions should be developed in order to directly improve growth through its individual effect and indirectly improve it via its effect on the banking sector.

Third, because the feedback hypothesis is also confirmed in the relationship between the banking sector and economic growth, we recommend that the banking sector's credit distribution capabilities should be strengthened. This will boost economic growth directly through its individual impact on growth and indirectly through its role in enhancing the insurance sector. 
Fourth, policies that stimulate economic growth should be actively pursued as this will lead to an attendant expansion in the financial sector.

The confirmation of the feedback hypothesis in the relationship between insurance market activities and economic growth and between banking sector activities and economic growth is an indication that endogeneity exists in the financial sector-economic growth relationship. The results also suggest that banking sector, insurance market activity, and economic growth are endogenous, and therefore any single equation forecast of one or the other could be misleading.

\section{Acknowledgements}

The authors are grateful to the editor and two anonymous referees for helpful comments and suggestions. Chien-Chiang Lee is grateful to the Ministry of Science and Technology of Taiwan for financial support through grant (MOST 107-2410-H-110-005-MY2).

\section{References}

Acemoglu, D. (1996). A microfoundation for social increasing returns in human capital accumulation. The Quarterly Journal of Economics, 111(3), 779-804.

Al-Yousif, Y. K. (2002). Financial development and economic growth: Another look at the evidence from developing countries. Review of Financial Economics, 11(2), 131-150.

Anderson, T. W., \& Hsiao, C. (1981). Estimation of dynamic models with error components. Journal of the American statistical Association, 76(375), 598-606.

Ang, J. B. (2008). What are the mechanisms linking financial development and economic growth in Malaysia? Economic Modelling, 25(1), 38-53.

Ang, J. B., \& McKibbin, W. J. (2007). Financial liberalization, financial sector development and growth: Evidence from Malaysia. Journal of Development Economics, 84(1), 215-233.

Arellano, M., \& Bond, S. (1991). Some tests of specification for panel data: Monte Carlo evidence and an application to employment equations. The Review of Economic Studies, 58(2), 277297. 
Arellano, M., \& Bover, O. (1995). Another look at the instrumental variable estimation of errorcomponents models. Journal of Econometrics, 68(1), 29-51.

Baltagi, B. H. (2008). Econometric analysis of panel data. Chichester: John Wiley and Sons.

Barro, R. J. (1991). Economic growth in a cross section of countries. The Quarterly Journal of Economics, 106(2), 407-443.

Baum, C. F. (2006). An Introduction to Modern Econometrics Using Stata. College Station, TX: Stata press.

Beck, T., \& Levine, R. (2004). Stock markets, banks, and growth: Panel evidence. Journal of Banking and Finance, 28(3), 423-442.

Beck, T., \& Webb, I. (2003). Economic, demographic, and institutional determinants of life insurance consumption across countries. The World Bank Economic Review, 17(1), 51-88.

Beck, T., Demirgüç-Kunt, A., \& Maksimovic, V. (2005). Financial and legal constraints to growth: Does firm size matter? The Journal of Finance, 60(1), 137-177.

Beenstock, M., Dickinson, G., \& Khajuria, S. (1988). The relationship between property-liability insurance premiums and income: An international analysis. The Journal of Risk and Insurance, 259-272.

Bernoth, K., \& Pick, A. (2011). Forecasting the fragility of the banking and insurance sectors. Journal of Banking and Finance, 35(4), 807-818.

Blundell, R., \& Bond, S. (1998). Initial conditions and moment restrictions in dynamic panel data models. Journal of Econometrics, 87(1), 115-143.

Bojanic, A. N. (2012). The impact of financial development and trade on the economic growth of Bolivia. Journal of Applied Economics, 15(1), 51-70.

Browne, M. J., \& Kim, K. (1993). An international analysis of life insurance demand. The Journal of Risk and Insurance, 60(4), 616-634.

Calderón, C., \& Liu, L. (2003). The direction of causality between financial development and economic growth. Journal of Development Economics, 72(1), 321-334.

Chen, P. F., Lee, C. C., \& Lee, C. F. (2012). How does the development of the life insurance market affect economic growth? Some international evidence. Journal of International Development, 24(7), 865-893.

Cheng, X., \& Degryse, H. (2010). The impact of bank and non-bank financial institutions on local economic growth in China. Journal of Financial Services Research, 37(2-3), 179-199. 
Ching, K. S., Kogid, M., \& Furuoka, F. (2010). Causal relation between life insurance funds and economic growth: Evidence from Malaysia. ASEAN Economic Bulletin, 27(2), 185-199.

Demetriades, P. O., \& Hussein, K. A. (1996). Does financial development cause economic growth? Time-series evidence from 16 countries. Journal of Development Economics, 51(2), 387411.

Demirgüç-Kunt, A., \& Maksimovic, V. (1998). Law, finance, and firm growth. The Journal of Finance, 53(6), 2107-2137.

Driffill, J., Psaradakis, Z., \& Sola, M. (1998). Testing the expectations hypothesis of the term structure using instrumental variables. International Journal of Finance \& Economics, 3(4), 321-325.

Emirmahmutoglu, F., \& Kose, N. (2011). Testing for Granger causality in heterogeneous mixed panels. Economic Modelling, 28(3), 870-876.

Fisher, R. A. (1932). Statistical methods for research workers (4th ed.). Oliver and Boyd, Edinburgh.

Goldsmith, R. W. (1969). Financial structure and development. New Haven: Yale University Press.

Grossman, G. M., \& Helpman, E. (1993). Innovation and Growth in the Global Economy. Cambridge: MIT press.

Haiss, P., \& Sümegi, K. (2008). The relationship between insurance and economic growth in Europe: A theoretical and empirical analysis. Empirica, 35(4), 405-431.

Han, L., Li, D., Moshirian, F., \& Tian, Y. (2010). Insurance development and economic growth. The Geneva Papers on Risk and Insurance-Issues and Practice, 35(2), 183-199.

Hosseini, H. M., \& Kaneko, S. (2011). Dynamic sustainability assessment of countries at the macro level: A principal component analysis. Ecological Indicators, 11(3), 811-823.

Hosseini, H. M., \& Kaneko, S. (2012). Causality between pillars of sustainable development: Global stylized facts or regional phenomena? Ecological Indicators, 14(1), 197-201.

King, R. G., \& Levine, R. (1993a). Finance and growth: Schumpeter might be right. The Quarterly Journal of Economics, 108(3), 717-737.

King, R. G., \& Levine, R. (1993b). Finance, entrepreneurship and growth. Journal of Monetary Economics, 32(3), 513-542. 
Körner, T., \& Schnabel, I. (2009). When do state-owned banks hamper economic growth? 7th Workshop on "Money, Banking and Financial Markets," Halle Institute for Economic Research.

Kugler, M., \& Ofoghi, R. (2005). Does insurance promote economic growth? Evidence from the $U K$. Money Macro and Finance (MMF) Research Group Conference, Money Macro and Finance Research Group.

Lee, C. C. (2013). Insurance and real output: The key role of banking activities. Macroeconomic Dynamics, 17(2), 235-260.

Lee, C. C., \& Hsieh, M. F. (2013). The impact of bank capital on profitability and risk in Asian banking. Journal of International Money and Finance, 32, 251-281.

Lee, C. C., \& Chang, C. H. (2015). Financial policy and insurance development: Do financial reforms matter and how? International Review of Economics and Finance, 38, 258-278.

Levine, R. (1997). Financial development and economic growth: Views and agenda. Journal of Economic Literature, 35(2), 688-726.

Levine, R., Loayza N., \& Beck, T. (2000). Financial intermediation and growth: Causality and causes. Journal of Monetary Economics, 46(1), 31-77.

Liang, Q., \& Jian-Zhou, T. (2006). Financial development and economic growth: Evidence from China. China Economic Review, 17(4), 395-411.

Liu, G. C., Lee, C. C., \& He, L. (2016). The synergistic effects between insurance and credit markets on economic growth: Evidence from China. Global Economic Review, 45(1), 118.

Liu, G., \& Zhang, C. (2016). The dynamic linkage between insurance activities and banking credit: Some new evidence from global countries. International Review of Economics and Finance, 44, 40-53.

Loayza, N. V., \& Ranciere, R. (2006). Financial development, financial fragility, and growth. Journal of Money, Credit and Banking, 38(4), 1051-1076.

Lucas Jr., R. E. (1988). On the mechanics of economic development. Journal of Monetary Economics, 22(1), 3-42.

Mankiw, N. G., Romer, D., \& Weil, D. N. (1992). A contribution to the empirics of economic growth. The Quarterly Journal of Economics, 107(2), 407-437. 
McKinnon, R. I. (1973). Money and Capital in Economic Development. Washington: Brookings Institution Press.

Mukhopadhyay, B., Pradhan, R. P., \& Feridun, M. (2011). Finance-growth nexus revisited for some Asian countries. Applied Economics Letters, 18(16), 1527-1530.

Outreville, J. F. (1990). The economic significance of insurance markets in developing countries. The Journal of Risk and Insurance, 57(3), 487-498.

Pan, G., \& Su, C. W. (2012). The relationship between insurance development and economic growth: A cross-region study for China. 2012 China International Conference on Insurance and Risk Management.

Panopoulou, E. (2009). Financial variables and euro area growth: A non-parametric causality analysis. Economic Modelling, 26(6), 1414-1419.

Pradhan, R. P., Arvin, B. M., Norman, N. R., \& Nishigaki, Y. (2014). Does banking sector development affect economic growth and inflation? A panel cointegration and causality approach. Applied Financial Economics, 24(7), 465-480.

Pradhan, R. P., Arvin, B. M., Norman, N. R., Nair, M., \& Hall, J. H. (2016). Insurance penetration and economic growth nexus: Cross-country evidence from ASEAN. Research in International Business and Finance, 36, 447-458.

Pradhan, R. P., Arvin, M. B., Hall, J. H., \& Bahmani, S. (2014). Causal nexus between economic growth, banking sector development, stock market development, and other macroeconomic variables: The case of ASEAN countries. Review of Financial Economics, 23(4), 155-173.

Pradhan, R. P., Arvin, M. B., Nair, M., Hall, J. H., \& Gupta, A. (2017). Is there a link between economic growth and insurance and banking sector activities in the G-20 countries? Review of Financial Economics, 33(1), 12-28.

Pradhan, R. P., Bahmani, S., \& Kiran, M. U. (2014). The dynamics of insurance sector development, banking sector development and economic growth: Evidence from G-20 countries. Global Economics and Management Review, 19(1-2), 16-25.

Pradhan, R. P., Dasgupta, P., \& Samadhan, B. (2013). Finance, development and economic growth in BRICS: A panel data analysis. Journal of Quantitative Economics, 11(1-2), 308-322.

Pradhan, R. P., Kiran, M. U., Dash, S., Chatterjee, D., Zaki, D. B., \& Maradana, R. (2015). Development of insurance sector and economic growth: The G-20 experience. South Asian Journal of Management, 22(1), 73-96. 
Pradhan, R. P., Mukhopadhyay, B., Gunashekar, A., Samadhan, B., \& Pandey, S. (2013). Financial development, social development, and economic growth: The causal nexus in Asia. Decision, 40(1-2), 69-83.

Pradhan, R. P., Tripathy, S., Chatterjee, D., Zaki, D. B., \& Mukhopadhyay, B. (2014). Development of banking sector and economic growth: The ARF experience. Decision, 41(3), 245-259.

Rajan, R. G., \& Zingales, L. (1998). Financial development and growth. The American Economic Review, 88(3), 559-586.

Rebelo, S. (1991). Long-run policy analysis and long-run growth. Journal of Political Economy, 99(3), 500-521.

Robinson, J. (1952). The generalization of the general theory. In The rate of interest and other essays (pp. 67-142). London: MacMillan.

Romer, P. M. (1986). Increasing returns and long-run growth. Journal of Political Economy, 94(5), 1002-1037.

Roodman, D. 2006. How to do xtabond2: An introduction to difference and system GMM in Stata. Center for Global Development Working Paper No. 103.

Roodman, D. (2009). A note on the theme of too many instruments. Oxford Bulletin of Economics and Statistics, 71(1), 135-158.

Samargandi, N., Fidrmuc, J., \& Ghosh, S. (2015). Is the relationship between financial development and economic growth monotonic? Evidence from a sample of middle-income countries. World Development, 68, 66-81.

Schumpeter, J. A. (1934). The theory of economic development. Cambridge, MA: Harvard University Press.

Seyoum, M., Wu, R., \& Lin, J. (2014). Foreign direct investment and trade openness in SubSaharan economies: A panel data Granger causality analysis. South African Journal of Economics, 82(3), 402-421.

Shaw, E. S. (1973). Financial Deepening in Economic Development. New York: OUP.

Song, F., \& Thakor, A. V. (2010). Financial system architecture and the co-evolution of banks and capital markets. The Economic Journal, 120(547), 1021-1055. 
Tennant, D., \& Abdulkadri, A. (2010). Empirical exercises in estimating the effects of different types of financial institutions' functioning on economic growth. Applied Economics, 42(30), 3913-3924.

Ward, D., \& Zurbruegg, R. (2000). Does insurance promote economic growth? Evidence from OECD countries. The Journal of Risk and Insurance, 67(4), 489-506.

Webb, I. P., Grace, M. F., \& Skipper, H. D. (2002). The effect of banking and insurance on the growth of capital and output. Centre for Risk Management and Insurance Working Paper No. 02-1, Robinson College of Business, Georgia State University.

Wolde-Rufael, Y. (2009). Re-examining the financial development and economic growth nexus in Kenya. Economic Modelling, 26(6), 1140-1146.

Zhang, J., Wang, L., \& Wang, S. (2012). Financial development and economic growth: Recent evidence from China. Journal of Comparative Economics, 40(3), 393-412.

Zou, H., \& Adams, M. B. (2006). The corporate purchase of property insurance: Chinese evidence. Journal of Financial Intermediation, 15(2), 165-196. 